\title{
PELATIHAN PEMBUATAN MEDIA PEMBELAJARAN BERBASIS TEKNOLOGI UNTUK PENDIDIK PAUD DI KEC BUKIT RAYA KOTA PEKANBARU
}

\author{
Roki Hardianto ${ }^{1}$, Sean Marta Efastri ${ }^{2}$, Eddissyah Putra Pane ${ }^{3}$ \\ 1,2,3 Universitas Lancang Kuning, Pekanbaru, Indonesia \\ e-mail : roki@unilak.ac.id, sean@unilak.ac.id, pane@unilak.ac.id
}

\begin{abstract}
Abstrak: Kegiatan Pengabdian Kepada Masyarakat dilaksanakan kepada Pendidik PAUD di Kecamatan Bukit Raya Kota Pekanbaru. Materi pelatihan yang diberikan pengetahuan teknologi dibidang Pendidikan Anak Usia Dini (PAUD). Apalagi dibanyak temuan dilapangan banyak guru / tenaga pendidik PAUD yang masih belum pendidikan sarjana, jika sudah pendidikan sarjana tetapi bukan dari lulusan sarjana PAUD. Teknologi disini bisa dimanfaatkan pada saat proses pembelajaran kepada peserta didik seperti dalam membuat media pembelajaran menggunakan media digital yang ditampilkan menggunakan projector, membuat video animasi pembelajaran atau video pembelajaran kreatif dan inovatif. Pendidik dikenalkan cara membuat slide presentasi yang dapat meningkatkan kemauan belajar anak. Luaran dari kegiatan ini adalah jurnal ilmiah yang dipublikasi, berita kegiatan yang dimuat / publikasi pada media massa online, modul ajar sebagai pegangan bagi tenaga pendidik. Dimasa pandemic, kegiatan dilaksanakan secara daring atau luring dengan menerapkan protokol kesehatan yang berlaku.
\end{abstract}

Kata Kunci: media pembelajaran, daring, PAUD, Covid-19, digital

Abstract: Community Service Activities are carried out for PAUD educators in Bukit Raya District, Pekanbaru City. The training materials are given knowledge of technology in the field of Early Childhood Education (PAUD). Moreover, there are many findings in the field that there are many PAUD teachers / educators who still have no undergraduate education, if they have undergraduate education but are not PAUD graduates. Technology here can be used during the learning process to students such as in making learning media using digital media displayed using a projector, making learning animation videos or creative and innovative learning videos. Educators are introduced to how to make presentation slides that can increase children's willingness to learn. The outputs of this activity are published scientific journals, news of activities published in online mass media, teaching modules as a guide for educators. During the pandemic, activities are carried out online or offline by applying the applicable health protocols.

Keywords: learning media, online, PAUD, Covid-19, digital

\section{Pendahuluan}

Himpunan Pendidik dan Tenaga Kependidikan Anak Usia Dini Indonesia (HIMPAUDI) adalah organisasi yang didalamnya terhimpun tenaga pendidik dan kependidikan PAUD yang bertujuan mengembangkan pengalaman dan pengetahuan untuk meningkatkan cara / proses belajar mengajar pada anak usia dini. 


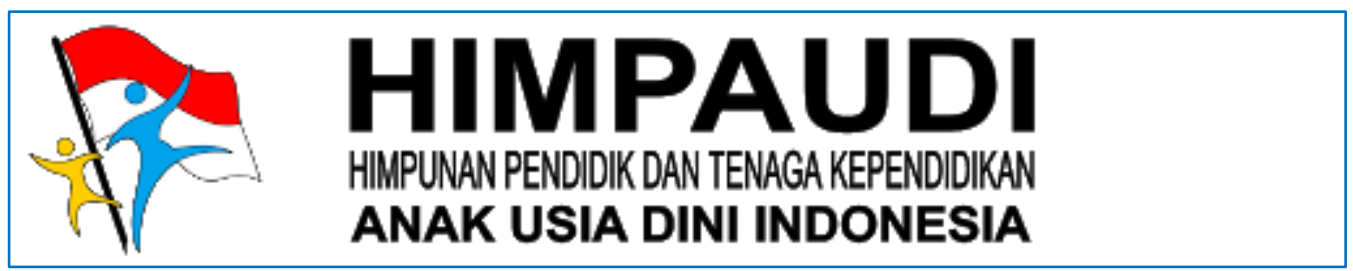

Gambar 1.1 Logo HIMPAUDI

HIMPAUDI sudah ada pada tingkat level bawah seperti kabupaten kota hingga kecamatan. Seperti halnya HIMPAUDI di Kecamatan Bukit Raya Kota Pekanbaru yang diketuai oleh Sri Juani Purwaningsih, S.Pd. Dalam melaksanakan proses belajar mengajar tenaga pendidik dan kependidikan PAUD masih menggunakan cara manual dan belum memanfaatkan penerapan komputer dan teknologi informasi. Hal ini disebabkan masih kurang keahlian tenaga pendidik dan kependidikan PAUD dalam pemahaman komputer dan teknologi. Hal lain juga masih banyak tenaga pendidik dan kependidikan PAUD berasal dari lulusan sarjana PAUD.

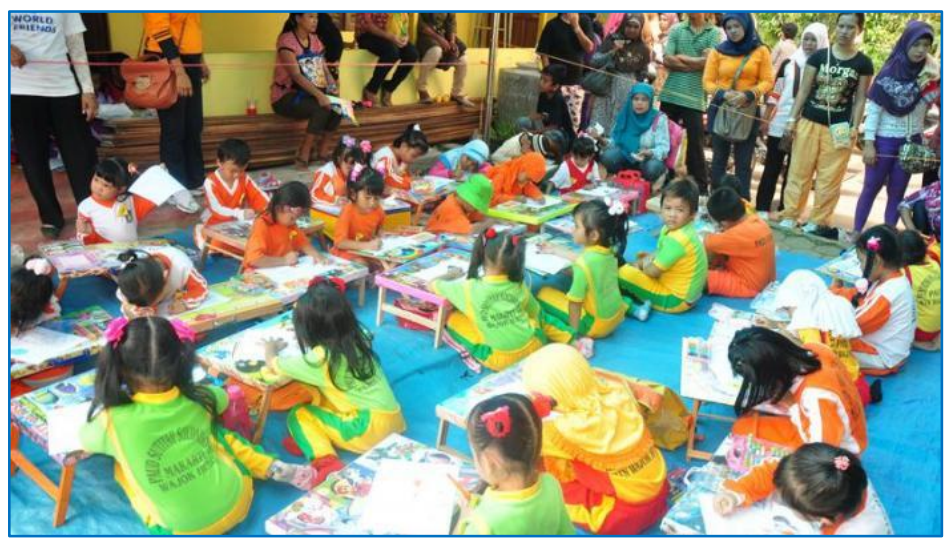

Gambar 1.2 Anak PAUD Sedang Belajar

Karena dengan penerapan teknologi dalam proses belajar PAUD dapat membantu meningkat daya belajar anak. Karena teknologi menyajikan kegiatan pembalajaran baru dan menarik.

\section{Metode}

Dalam masa pandemic Covid-19 ini pelaksanaan Pengabdian Kepada Masyarakat dengan metode webbinar secara daring atau tatap muka dengan menerapkan protokol kesehatan. Pelatihan dilakukan selama satu hari dimana peserta akan mendapatkan modul ajar untuk pelatihan.

Metode webinar menggunakan Zoom Meeting dapat dilakukan dengan penjelasan menggunakan slide persentasi dan handout materi yang sudah dikirim sebelumnya kepada peserta pelatihan. Pada awal pertemuan para tenaga pendidik dan kependidika akan diberikan materi pengantar dan dilanjutkan praktek langsung tentang penerapan teknologi informasi pada pelaksanaan proses belajar mengajar PAUD. Contoh kegiatannya adalah membuat slide presentasi menarik sebagai media pembelajaran dan membuat video pembelajaran inovatif dengan memanfaatkan aplikasi OBS Studia. Hal ini untuk mengetahui tingkat pengetahuan peserta dan menerima masukan untuk perbaikan pada kegiatan kegiatan berikutnya. Secara rinci kegiatan pengabdian yang akan dilakukan sebagai berikut

1. Kegiatan perkenalan

2. Pengenalan teknologi informasi dalam pendidikan 
3. Pendalaman materi pelatihan

4. Melakukan tanya jawab

5. Praktek langsung

Kegiatan ini menggunakan bebarapa perangkat pendukung di antaranya adalah :

1. Perangkat komputer / laptop

2. Projektor

3. Aplikasi Zoom Meeting

4. OBS Studio

5. Ms. Office Powerpoint

6. https://www.canva.com/

7. https://youtube.com/

\section{Hasil dan Pembahasan}

Pelaksanaan kegiatan Pengabdian Kepada Masyarakat dilaksanakan secara langsung di Aula Kantor Camat Bukit Raya, Pekanbaru pada hari Senen, 5 April 2021 jam 14.00 WIB. Hadir sebagai peserta adalah ketua HIMPAUDI Bukit Raya dan anggota HIMPAUDI Bukit Raya yang terdiri dari guru-guru di Kecamatan Bukit Raya, Kota Pekanbaru.

Tema dari Pengabdian Kepada Masyarakat adalah "Pelatihan Pembuatan Media Pembelajaran Berbasis Teknologi Untuk Pendidik PAUD Di Kec Bukit Raya Kota Pekanbaru". Maksudnya adalah guru-guru yang tergabung pada HIMPAUDI Bukit Raya diajarkan materi membuat video pembelajaran menggunakan aplikasi OBS Studio dengan memanfaatkan komputer serta pemanfaatan Microsoft Powerpoint dan website https://www.canva.com/ dan https://youtube.com/.

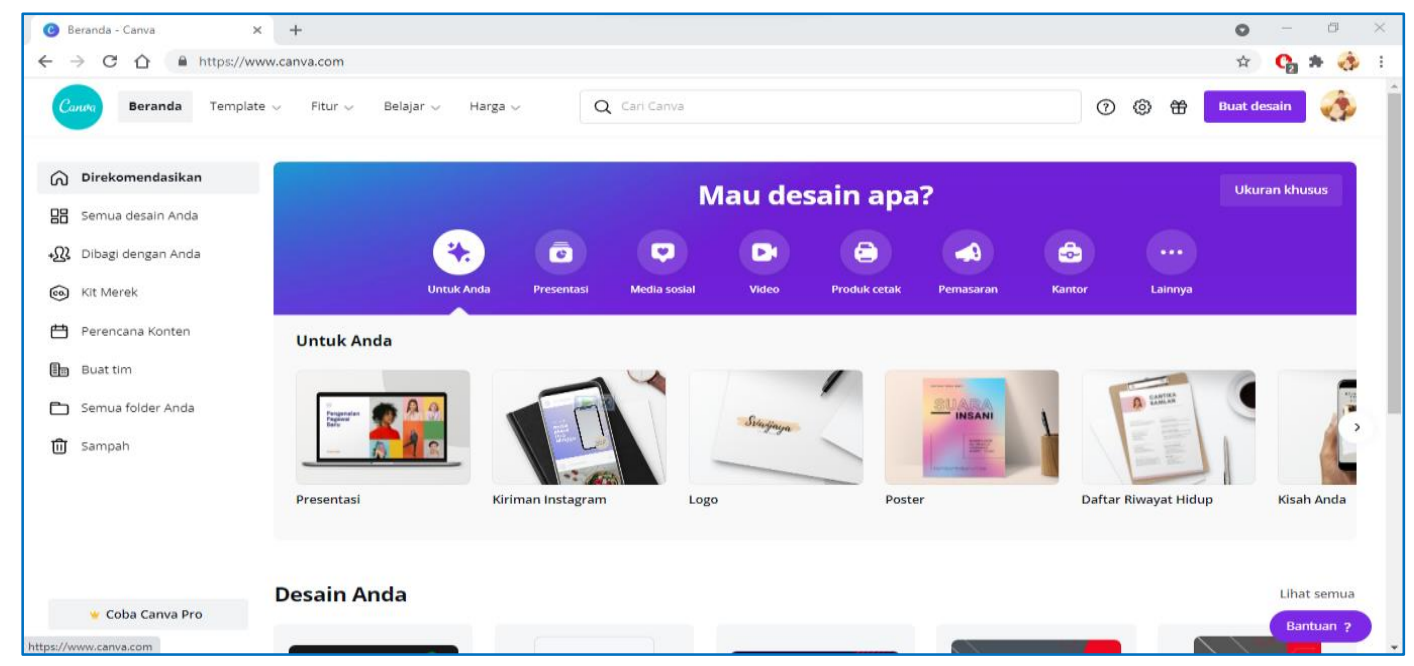

Gambar 5.1 Laman https://www.canva.com/ 


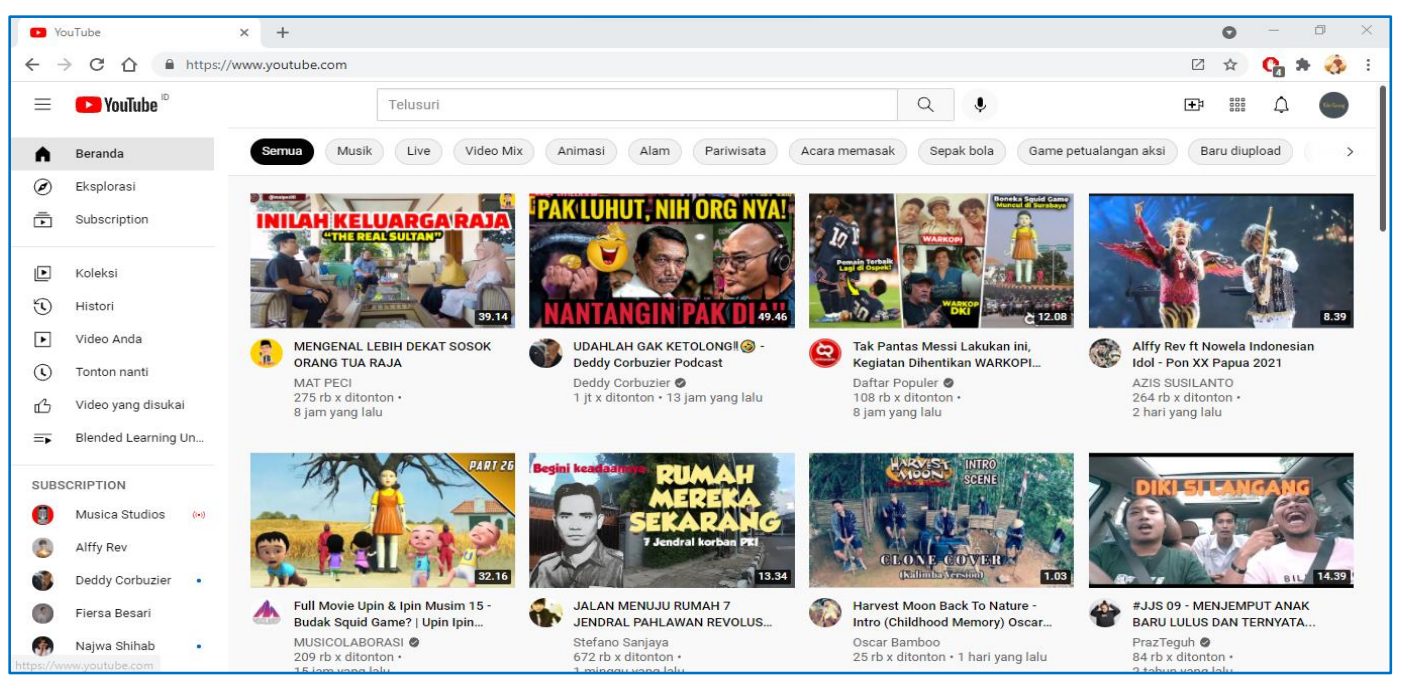

Gambar 5.2 Laman https://www.youtube.com/

Aplikasi OBS Studio adalah sebuah aplikasi Open Broadcaster Software Studio yang biasa digunakan dalam membuat dan mengolah video dengan kreatif untuk hal live webinar dari social media atau video offline. Dengan aplikasi ini pengguna dapat membuat sebuah video pembelajaran yang kreatif dan inovatif dengan mengkombinasikan beberapa aplikasi lain seperti power point atau gambar yang menarik. Aplikasi ini dapat di download pada link https://obsproject.com/ secara gratis.

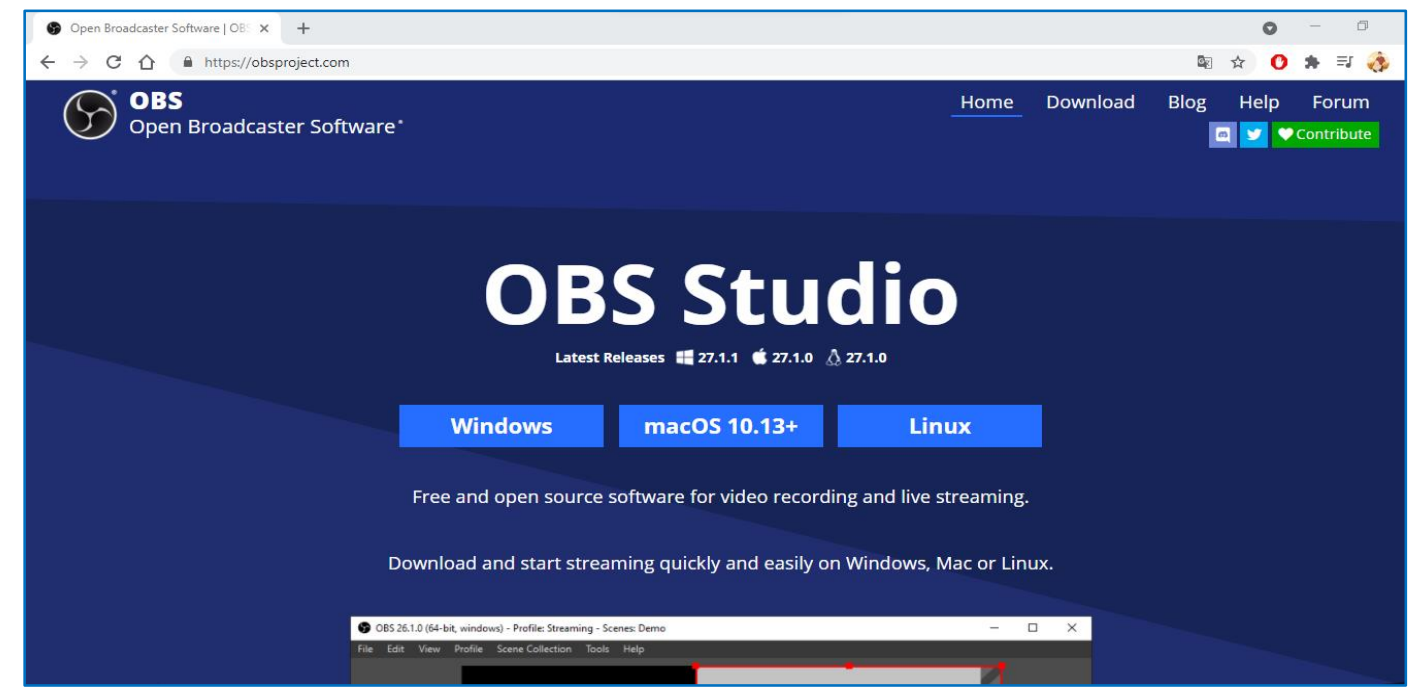

Gambar 5.3 Laman https://obsproject.com/ 


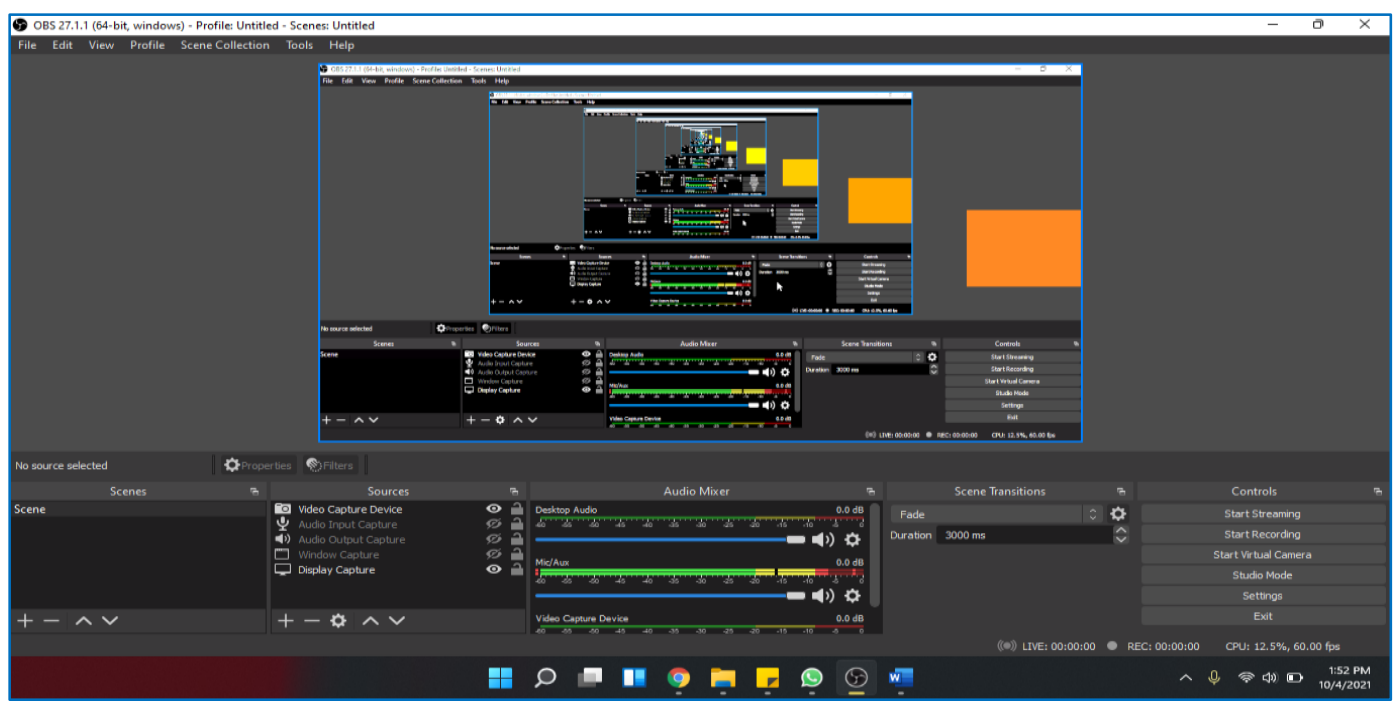

Gambar 5.4 Antar Muka OBS Studi Pada Komputer

Kegiatan dilaksanakan pemaparan materi menggenai alat dan media yang digunakan sebagai pendukung pembuatan media pembelajaran. Kemudian dilanjutkan dengan praktek dan sesi tanya jawab kemudian diakhiri dengan sesi foto bersama sebagai dokumentasi.

Ketua HIMPAUDI Kecamatan Bukit Raya, Sri Juani Purwaningsih, S.Pd pada sambutannya menyampaikan bahwa sangat mengapresiasi kegiatan Pengabdian Kepada Masyarakat dari Universitas Lancang Kuning karena sangat membantu anggota HIMPAUDI dari kalangan guru dalam mengasah kompetensi dibidang Teknologi Informasi khususnya pada pembelajaran di masa pandemi. Guru dituntut aktif, kreatif dan inovatif dalam proses pembelajaran secara hibrid maupun daring.

Pada saat pemaparan materi oleh narasumber tentang penggunaan https://www.canva.com/ dalam membuat media pembelajaran, peserta sangat antusias bertanya karena disamping menarik juga sangat mempermudah guru dalam membuat media pembelajaran. Selain itu https://www.canva.com/ dapat diakses secara gratis baik di smartphone maupun komputer.

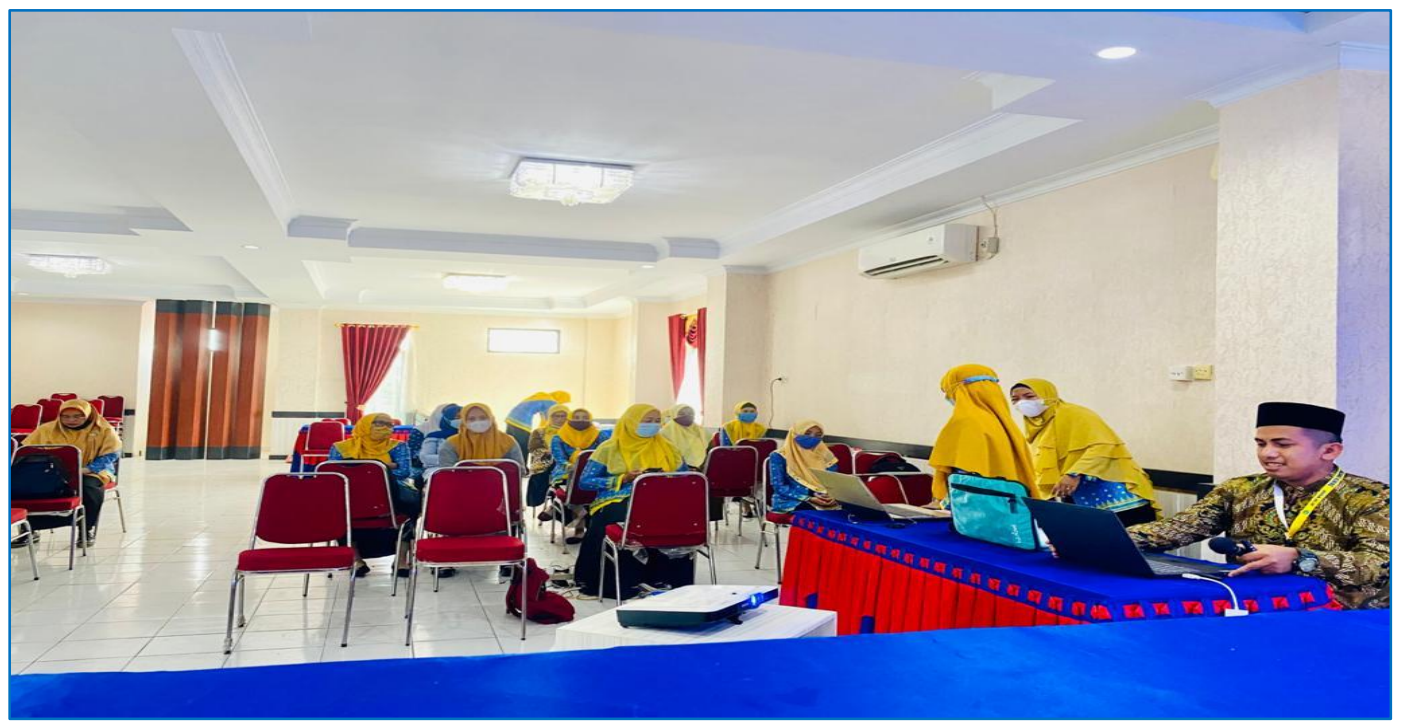




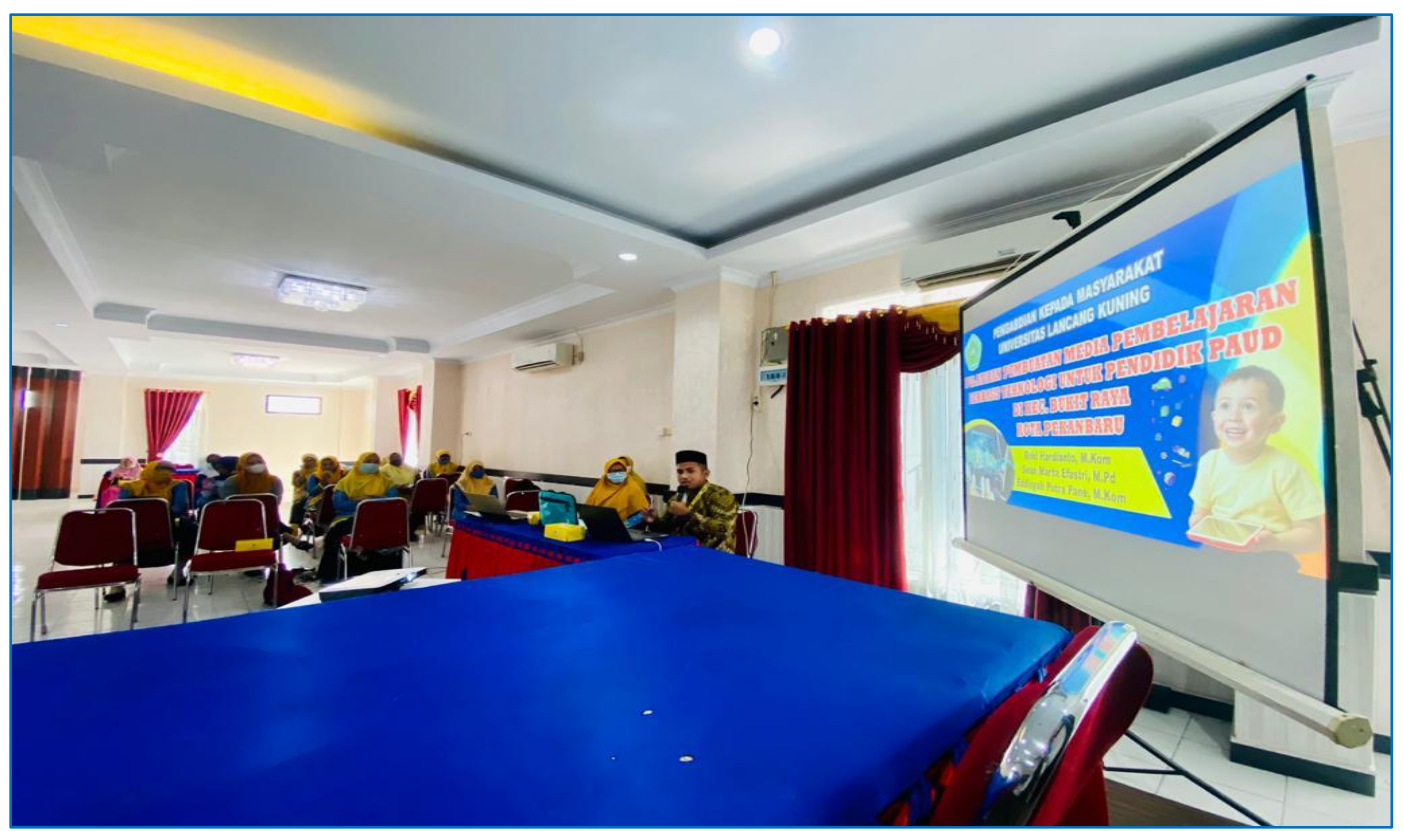

Gambar 5.5 Pemaparan Materi Oleh Narasumber

Diakhir sesi kegiatan dilaksanakan foto bersama antara tim pengabdian Kepada Masyarakat dengan peserta dari kalangan anggota HIMPAUDI Kecamatan Bukit Raya, yang terdiri atas guru dan tenaga pendidik maupun kepala sekolah PAUD. Diakhir sesi kegiatan pada saat penyapaian pesan dan kesan oleh peserta berharap akan adanya kegiatan lanjutan daripada kegiatan ini yang bertujuan mengasah kemampuan guru secara berkala dan berkelanjutan, karena rata-rata tenaga pendidik PAUD bukan berasal dari lulusan IT atau mengenyam pendidikan IT secara khusus.

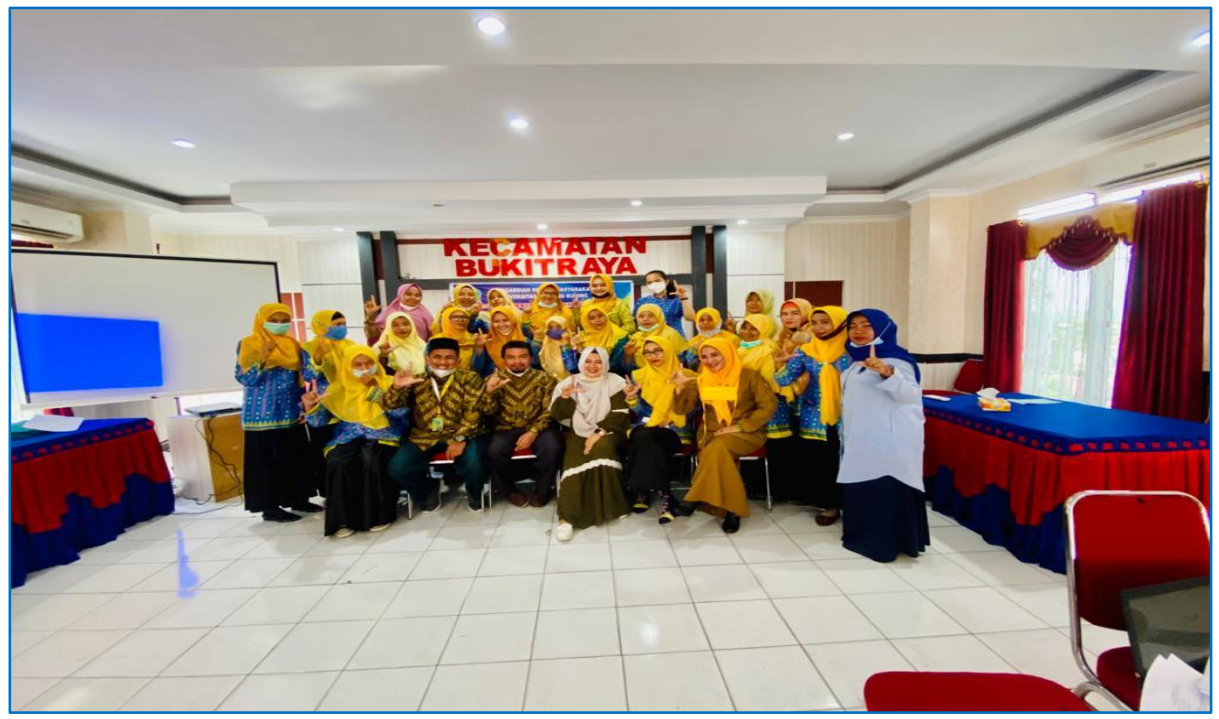




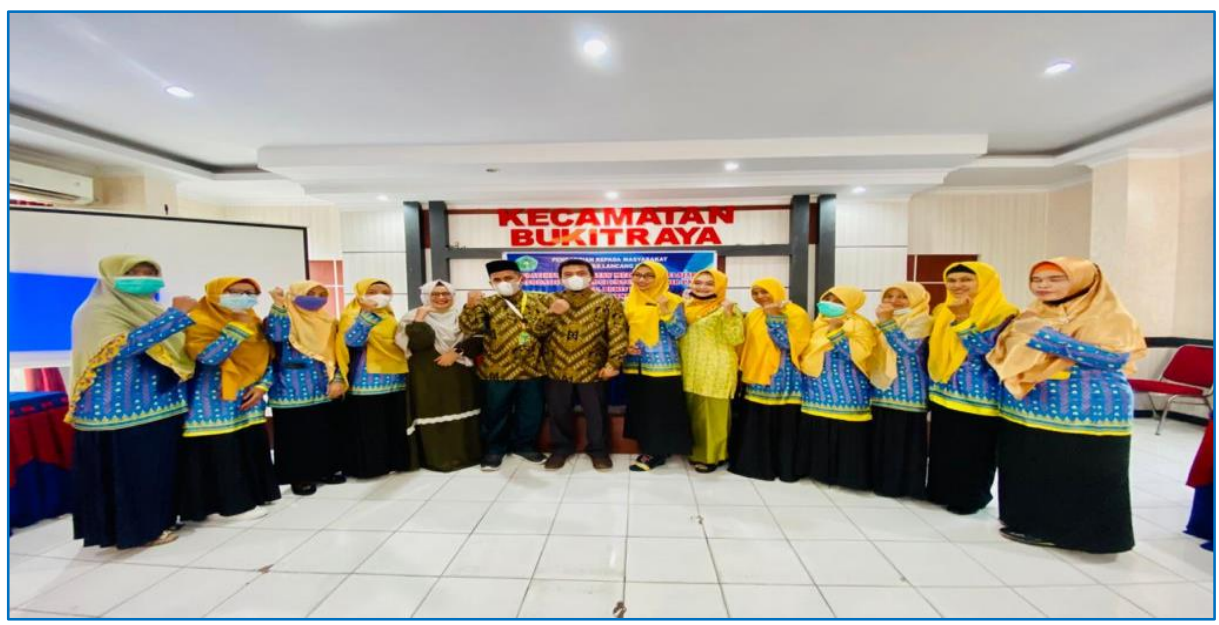

Gambar 5.6 Sesi Foto Bersama

Agar dapat melihat kompetensi peserta Pengabdian Kepada Masyarakat sebelum dan sesudah pelaksanaan kegiatan, maka disebarkan angket diawal dan diakhir kegiatan. Berikut ini adalah angket yang digunakan pada awal kegiatan :

\begin{tabular}{|c|c|c|c|}
\hline No & Pertanyaan & Jawaban & Point \\
\hline \multirow{2}{*}{1} & \multirow{2}{*}{$\begin{array}{l}\text { Apakah sekolah Bapak / Ibu sudah menggunakan media } \\
\text { dalam proses pembelajaran? }\end{array}$} & Sudah & 18 \\
\hline & & Belum & 4 \\
\hline \multirow{2}{*}{2} & \multirow{2}{*}{$\begin{array}{l}\text { Media yang digunakan dalam pembelajaran di sekolah } \\
\text { Bapak / lbu? }\end{array}$} & Media Dibuat dari Kertas & 17 \\
\hline & & Media Digital / Komputer & 5 \\
\hline \multirow{2}{*}{3} & \multirow{2}{*}{$\begin{array}{l}\text { Apakah di sekolah sudah menerapkan media } \\
\text { pembelajaran berbasis komputer / IT }\end{array}$} & Sudah & 5 \\
\hline & & Belum & 17 \\
\hline \multirow{2}{*}{4} & \multirow{2}{*}{$\begin{array}{l}\text { Apakah dalam proses pembelajaran guru } \\
\text { mengunakan laptop? }\end{array}$} & Sudah & 9 \\
\hline & & Belum & 13 \\
\hline \multirow{2}{*}{5} & \multirow{2}{*}{$\begin{array}{l}\text { Apakah media gunakan guru melalui YouTube atau } \\
\text { media daur ulang? }\end{array}$} & Youtube & 10 \\
\hline & & Media Daur Ulang & 12 \\
\hline \multirow{2}{*}{6} & \multirow{2}{*}{$\begin{array}{l}\text { Apakah tenaga pendidik di sekolah Bapak / lbu } \\
\text { memiliki mampu menggunakan laptop pada saat }\end{array}$} & Sudah & 15 \\
\hline & & Belum & 7 \\
\hline
\end{tabular}

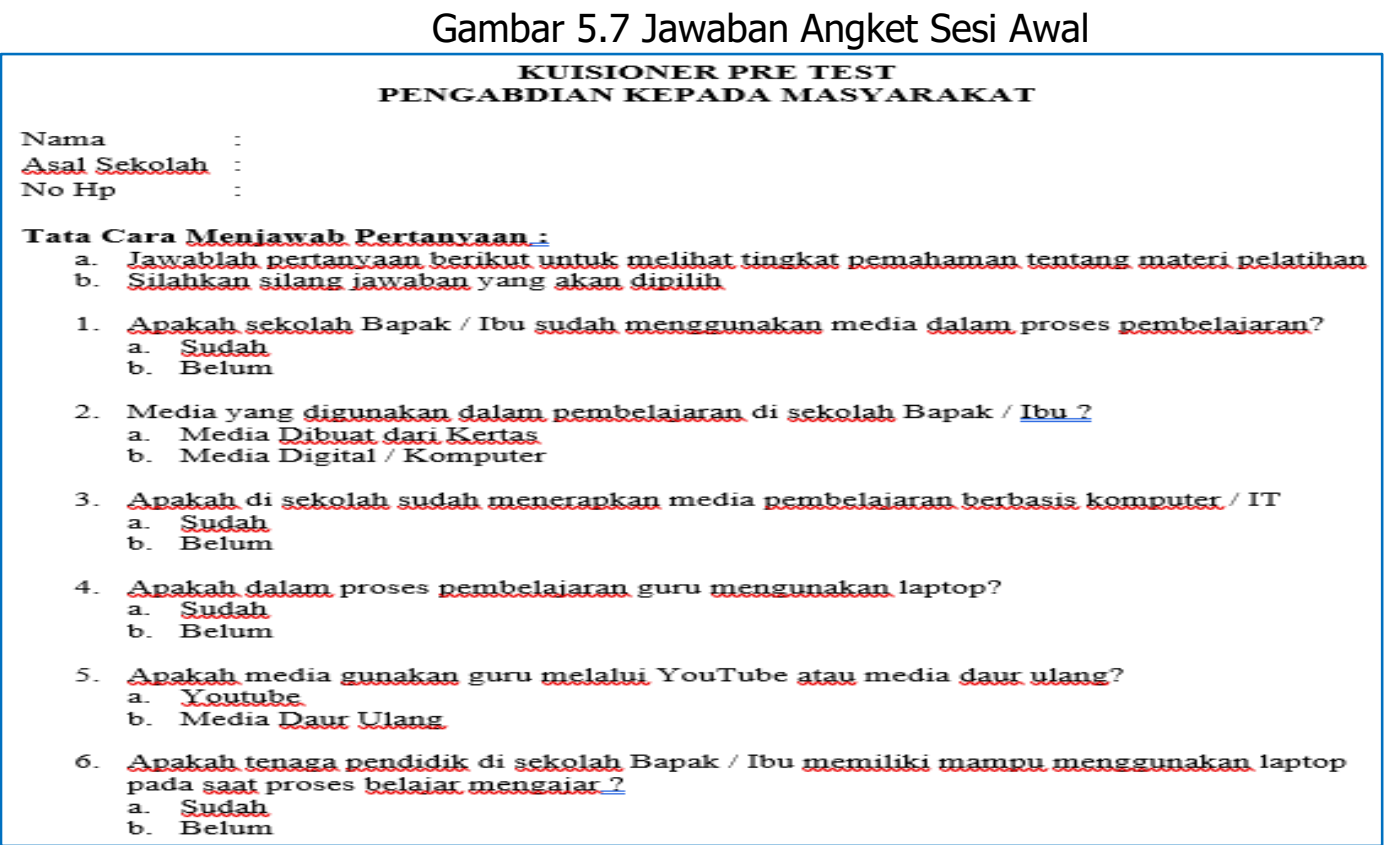




\section{Gambar 5.8 Angket Awal Kegiatan}

Berikut ini adalah persentase jawaban angket berdasarkan jumlah angket yang masuk dalam bentuk grafik.

1. Apakah sekolah Bapak / Ibu sudah menggunakan media dalam proses pembelajaran?

\section{Pertanyaan 1}

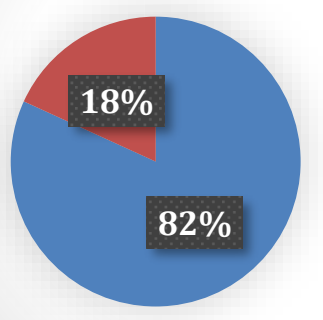

- Sudah

- Belum

2. Media yang digunakan dalam pembelajaran di sekolah Bapak / Ibu ?

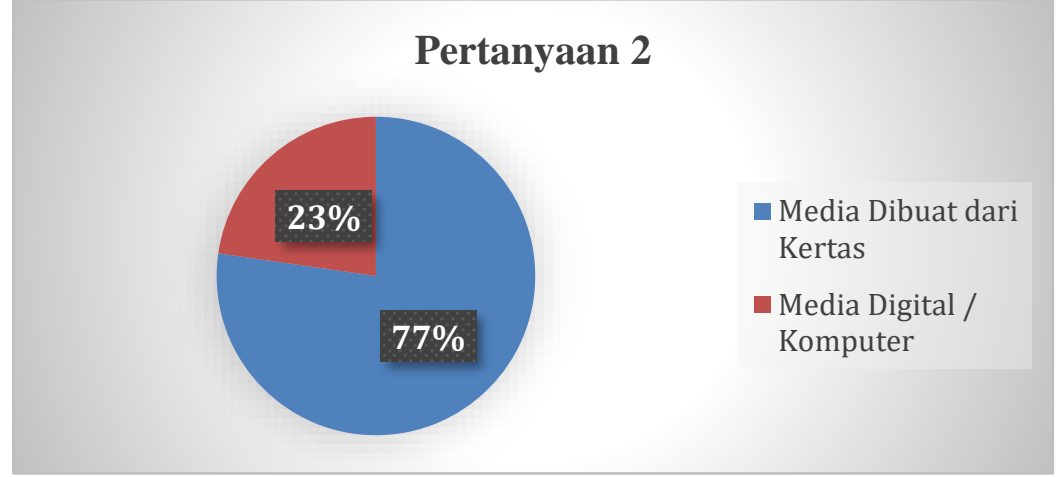

3. Apakah di sekolah sudah menerapkan media pembelajaran berbasis komputer / IT

Pertanyaan 3

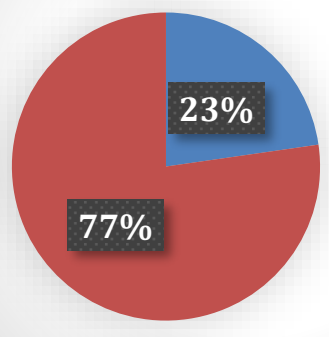

- Sudah

- Belum

4. Apakah dalam proses pembelajaran guru mengunakan laptop? 


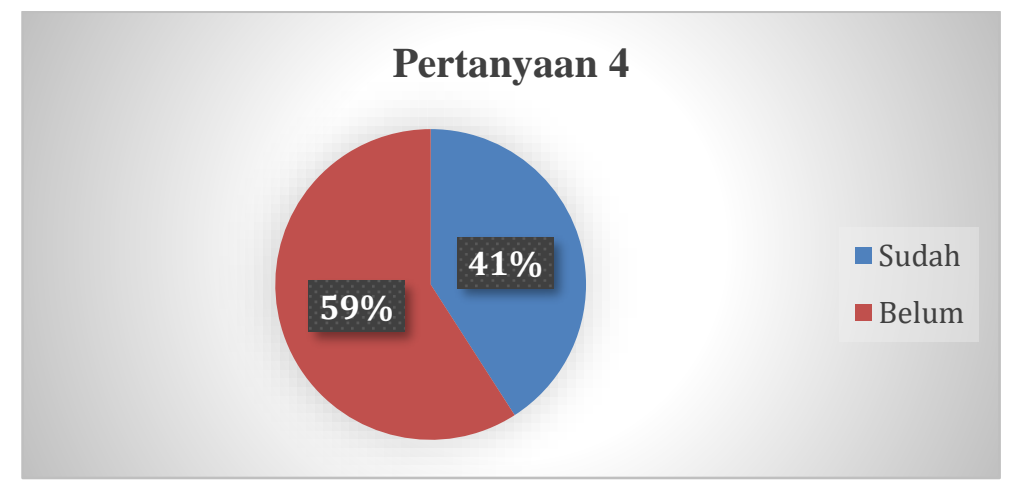

5. Apakah media gunakan guru melalui YouTube atau media daur ulang?

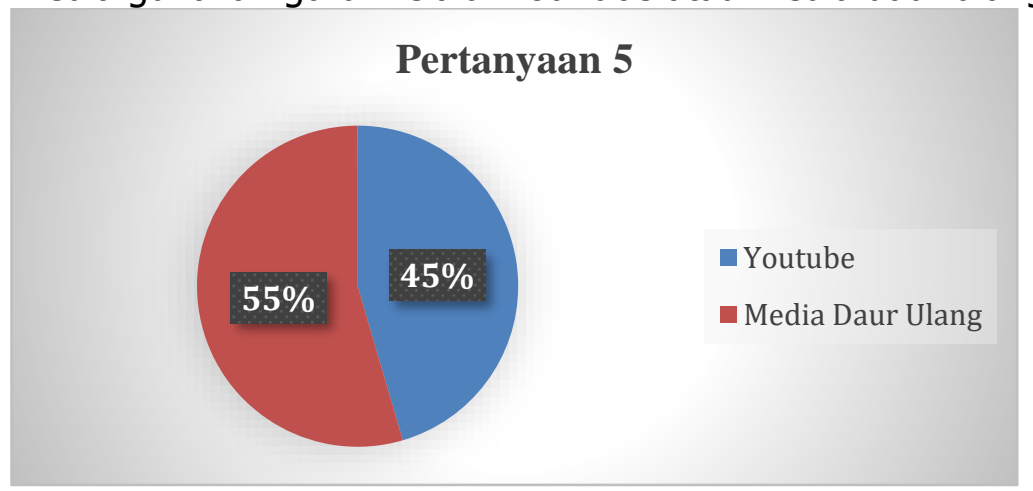

6. Apakah tenaga pendidik di sekolah Bapak / Ibu memiliki mampu menggunakan laptop pada saat proses belajar mengajar?

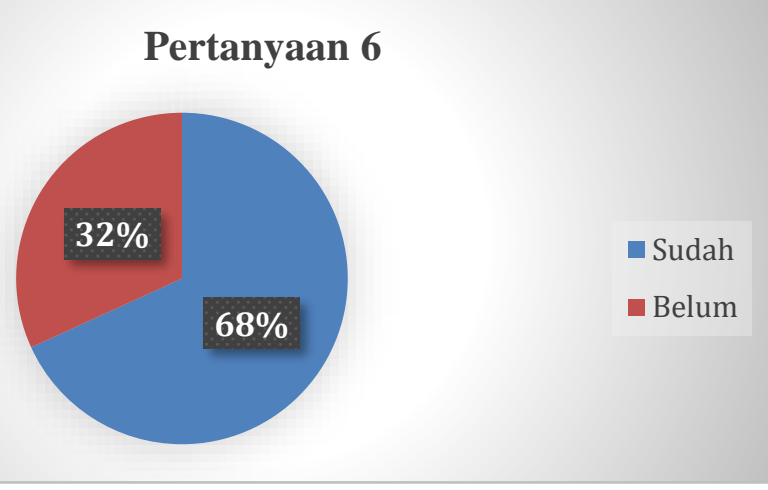

Secara umum dapat disimpulkan bahwa peserta belum mempunyai kompetensi lebih dalam penggunaan IT pada proses pembuatan media pembelajaran. Dibawah ini adalah angket pada sesi akhir kegitan Pengabdian Kepada Masyarakat, angket akhir ini untuk melihat tingkat pemahaman peserta selama kegiatan berlangsung. 


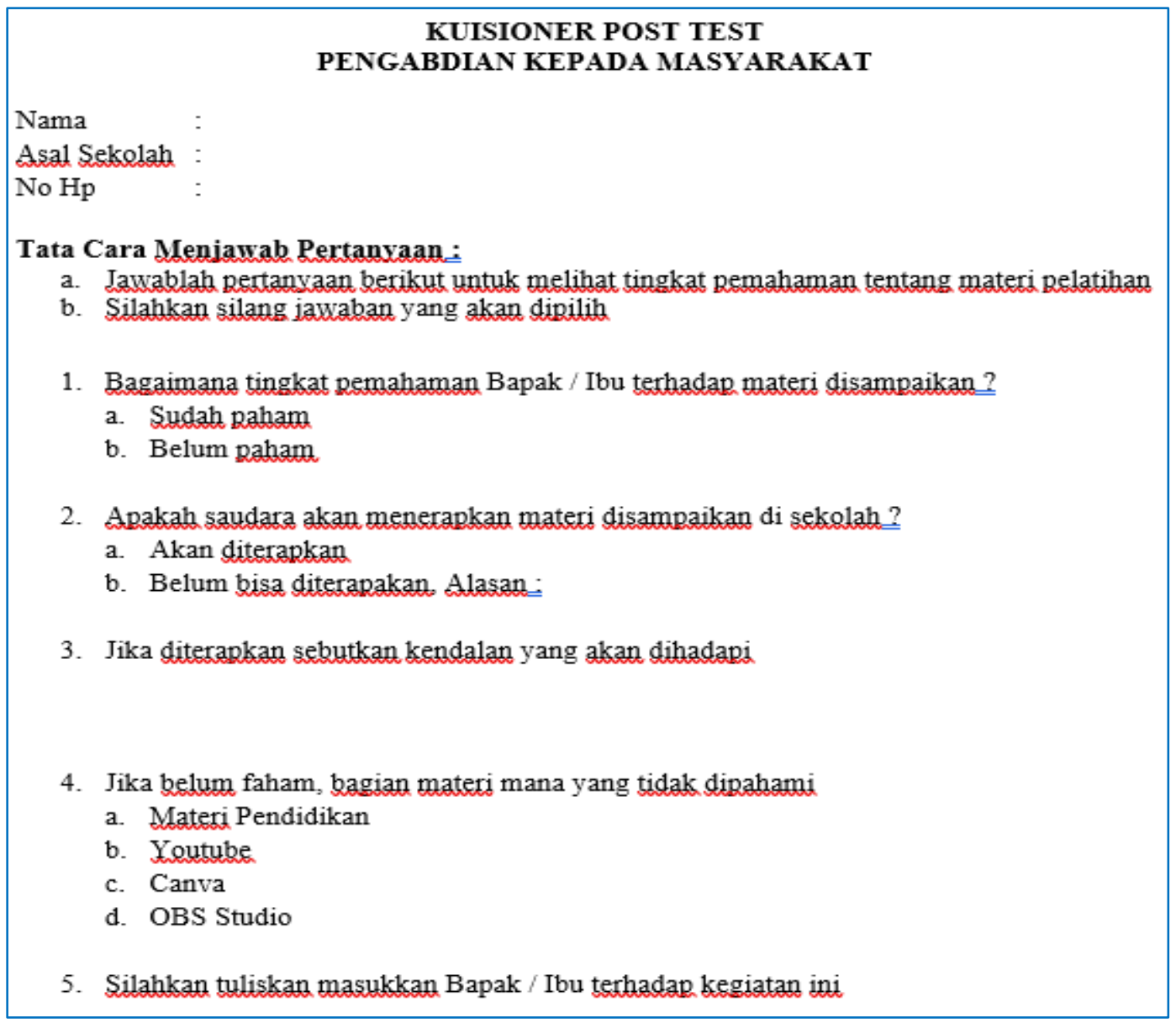

Gambar 5.9 Angket Sesi Akhir

Berikut ini adalah jawaban dari angket sesi akhir kegiatan

\begin{tabular}{|c|c|c|c|}
\hline No & Pertanyaan & Jawaban & Point \\
\hline \multirow[b]{2}{*}{1} & \multirow{2}{*}{$\begin{array}{l}\text { Bagaimana tingkat pemahaman Bapak / lbu terhadap materi } \\
\text { disampaikan? }\end{array}$} & Sudah Paham & 17 \\
\hline & & Belum Paham & 5 \\
\hline \multirow{2}{*}{2} & \multirow{2}{*}{$\begin{array}{l}\text { Apakah saudara akan menerapkan materi disampaikan di } \\
\text { sekolah? }\end{array}$} & Media Dibuat dari Kertas & 18 \\
\hline & & Media Digital / Komputer & 4 \\
\hline \multirow{2}{*}{3} & \multirow{2}{*}{ Jika diterapkan sebutkan kendalan yang akan dihadapi } & Akan diterapkan & \\
\hline & & Belum bisa diterapakan, Alasan & \\
\hline \multirow{4}{*}{4} & \multirow{4}{*}{ Jika belum faham, bagian materi mana yang tidak dipahami } & Materi Pendidikan & 2 \\
\hline & & Youtube & 2 \\
\hline & & Canva & 2 \\
\hline & & OBS Studio & 16 \\
\hline 5 & Silahkan tuliskan masukkan Bapak / lbu terhadap kegiatan ini & & \\
\hline
\end{tabular}

Gambar 5.10 Jawaban Angket Sesi Akhir

Berikut ini adalah persentase jawaban angket berdasarkan jumlah angket yang masuk dalam bentuk grafik.

1. Bagaimana tingkat pemahaman Bapak / Ibu terhadap materi disampaikan ? 


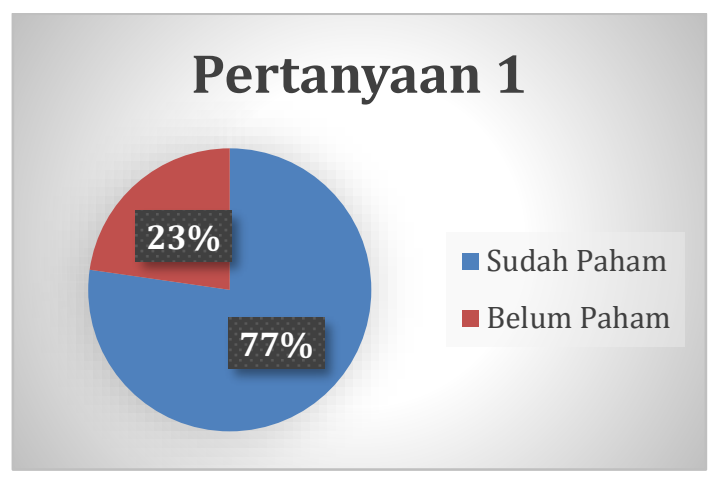

2. Apakah saudara akan menerapkan materi disampaikan di sekolah ?

\section{Pertanyaan 2}

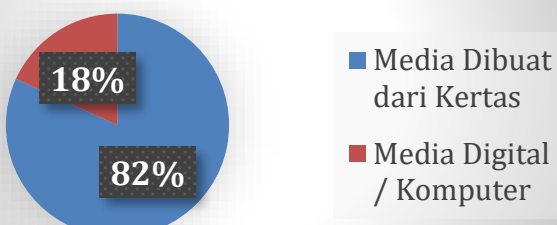

3. Jika diterapkan sebutkan kendalan yang akan dihadapi

4. Jika belum faham, bagian materi mana yang tidak dipahami

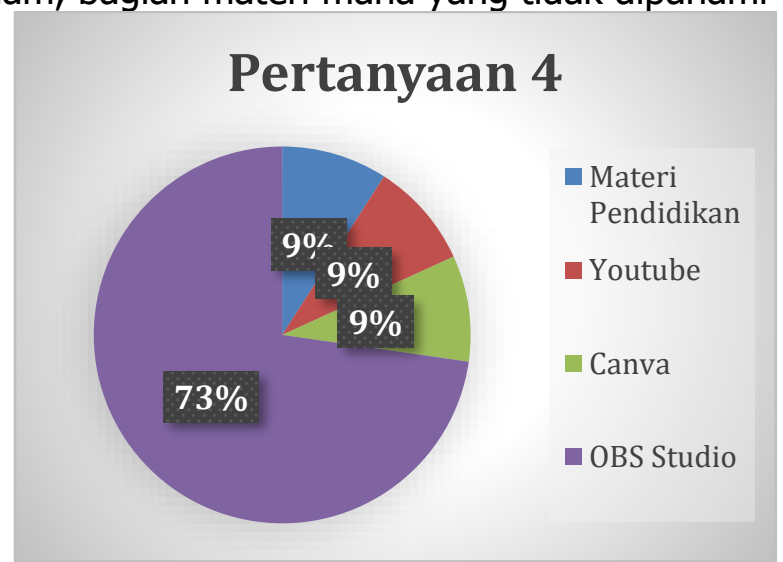

1. Silahkan tuliskan masukkan Bapak / Ibu terhadap kegiatan ini

Semua jawaban angket sesi awal dan akhir dilampirkan pada lampiran dibagian akhir laporan. Untuk penunjang pelaksanaan kegiatan Pengabdian, diperlukan spanduk yang dipasang pada kegiatan seperti dibawah ini. 


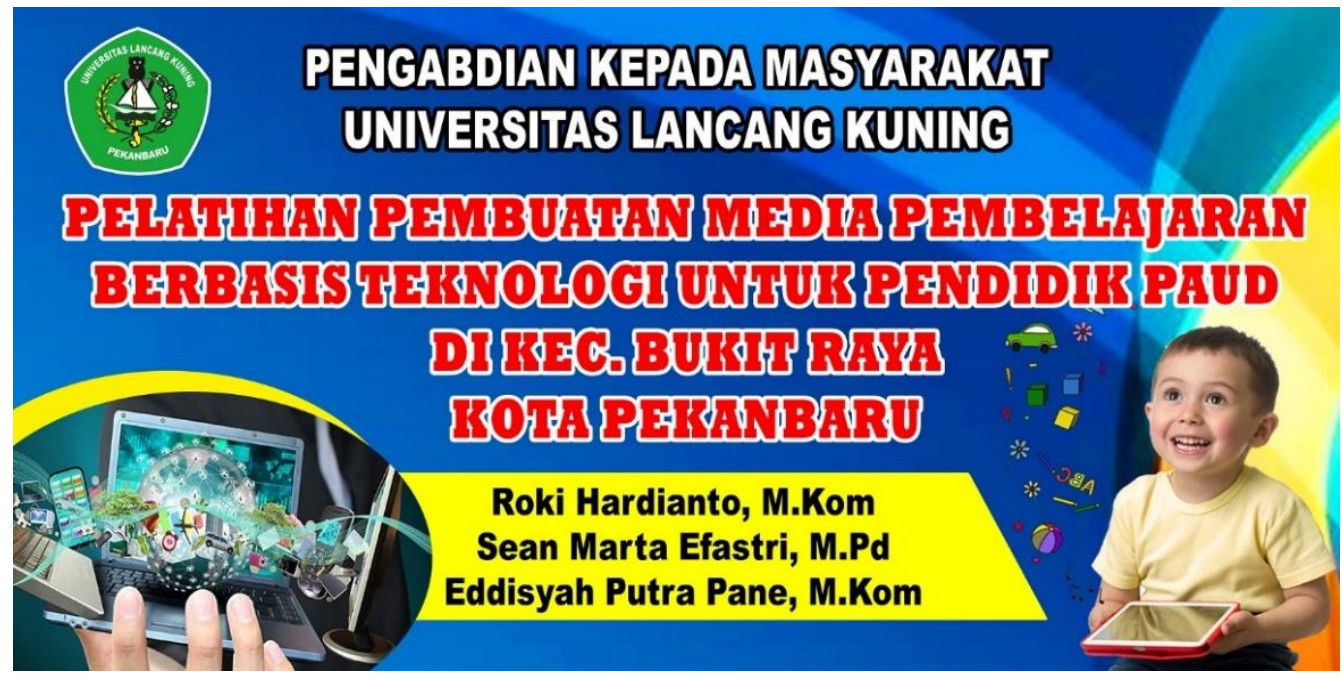

Gambar 5.11 Spanduk Informasi Pengabdian

Dari kegiatan pengabdian kepada masyarakat, luaran yang di capai adalah Berita kegiatan yang di terbitkan pada media berita online sapa riau pada link http://www.sapariau.com/berita/detail/kolaborasi-fasilkom-dan-fkip-unilak-laksanakanpengabdian-pembuatan-media-ajar-berbasis-it-

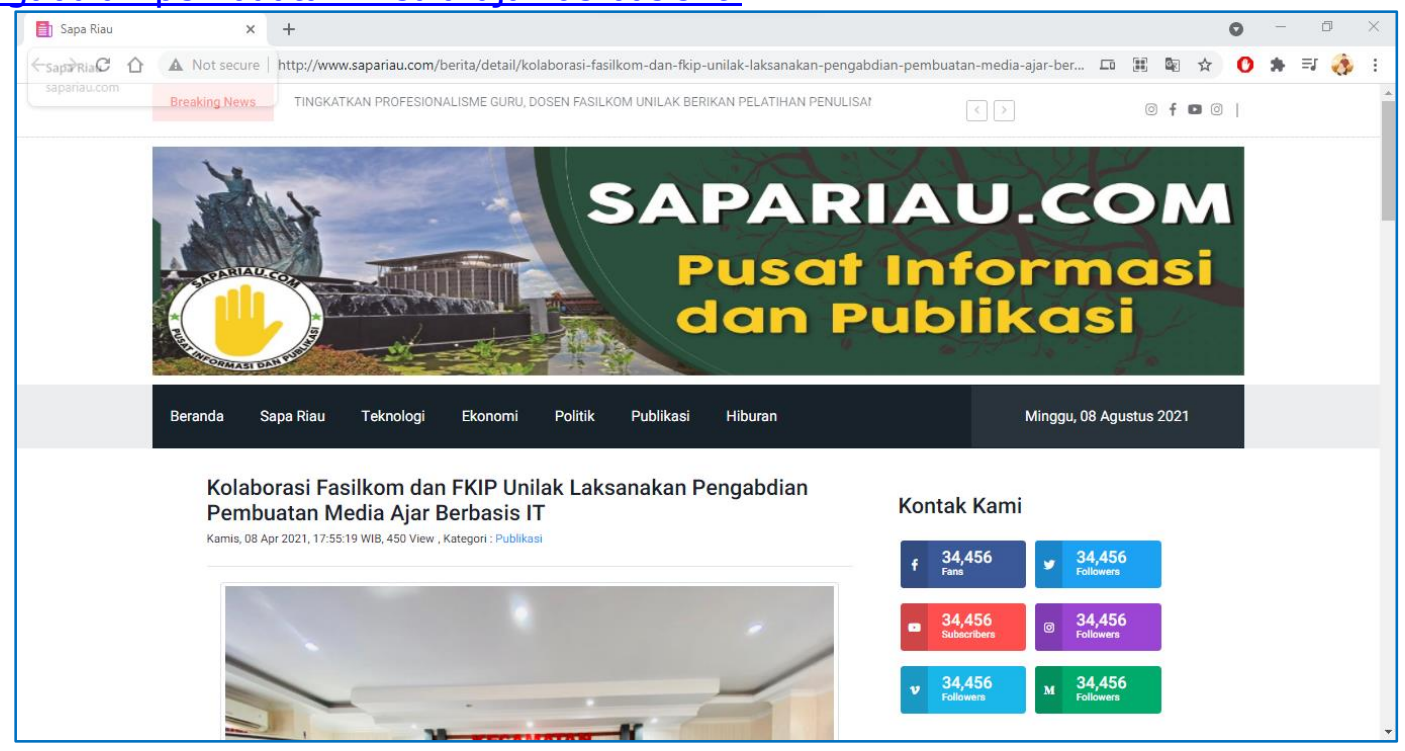

Gambar 5.12 Publikasi Kegiatan Pada Media Online Sapa Riau

Selain itu juga terbit pada website Fakultas Ilmu Komputer Universitas Lancang Kuning https://fasilkom.unilak.ac.id/berita/detail/kolaborasi-fasilkom-dan-fkip-unilak-laksanakanpengabdian-pembuatan-media-ajar-berbasis-it-kepada-gu 


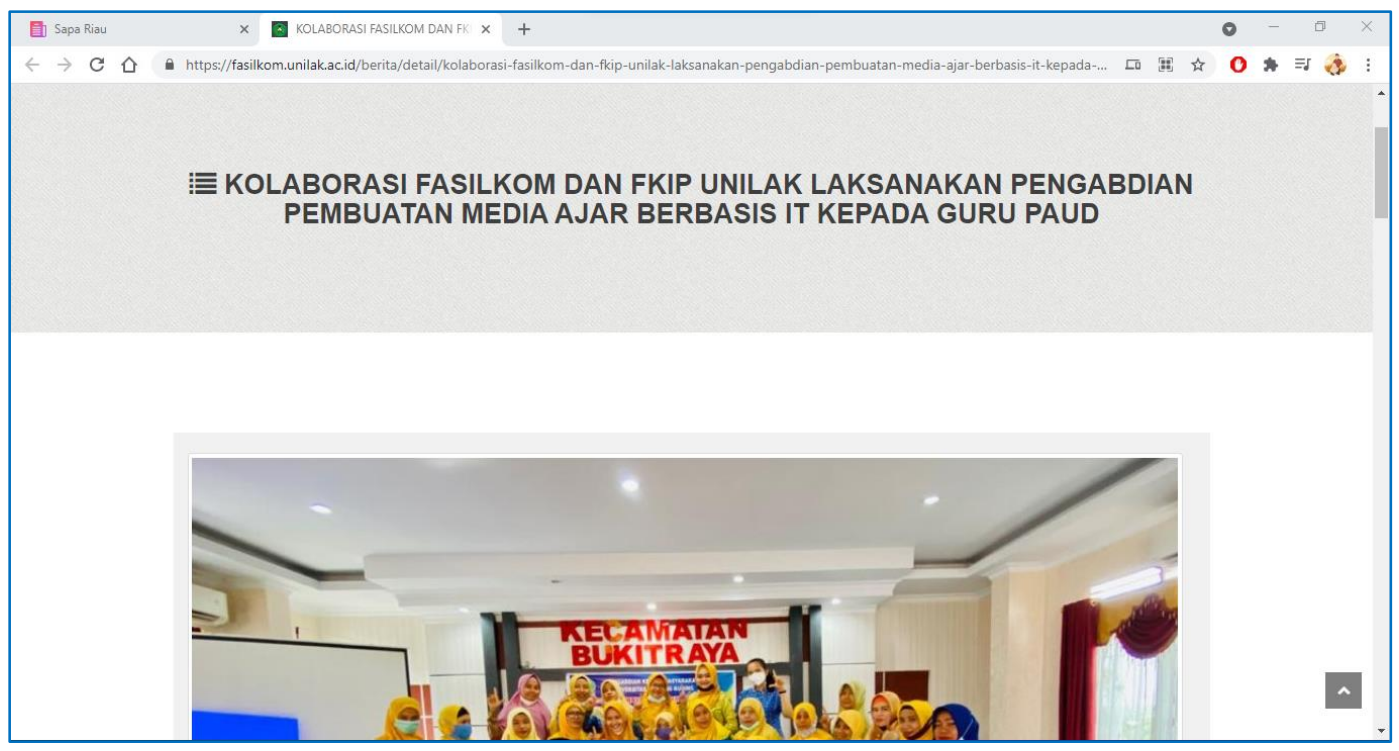

Gambar 5.13 Publikasi Kegiatan Pada Website Fakultas Ilmu Komputer

Tujuan dari berita adalah untuk mempublikasikan kegiatan Pengabdian Kepada Masyarakat yang telah dilaksanakan sebagai kegitan Tri Dharma Perguruan Tinggi dosen kepada masyarakat. Berita kegiatan dapat disebarluaskan dengan menggunakan social media berupa facebook, twitter, Instagram, whatsapp dan lainnya.

4. Kesimpulan (Tahoma, $11 \mathrm{pt}$, Bold)

Berdasarkan hasil pelaksanaan Pengabdian Kepada Masyarakat dengan tema "Pelatihan Pembuatan Media Pembelajaran Berbasis Teknologi Untuk Pendidik PAUD Di Kec Bukit Raya Kota Pekanbaru" adalah

1. Pengabdian dirasakan manfaat oleh anggota HIMPAUDI Kecamatan Bukit Raya berupa pengetahuan membuat media pembelajaran kreatif, inovatif dan keren.

2. Tidak semua guru mampu menerapkan pembelajaran daring kepada siswa PAUD, baik karena keterbatasan perangkat juga karena tidak memiliki keterampilan dalam bidang IT

3. Siswa PAUD dalam proses pembelajaran memerlukan pendampingan extra khususnya pada pembelajaran daring di masa pandemi.

4. Dibutuhkan pendampingan khusus kepada guru dalam membuat media pembelajaran.

5.

\section{Ucapan Terima Kasih}

Terimakasih kepada LPPM Universitas Lancang Kuning telah mensupport kegiatan ini, serta juga terimakasih kepada HIMPAUDI Kecamatan Bukit Raya telah mensukseskan acara semoga menjadi amal ibadah Bersama. Serta terimakasih kepada tim pengabdian yang selalu membantu dalam menyelesaikan kegiatan hingga laporan akhir. Terimakasih kepada Allah SWT yang selalu menjaga tim pengabdian dari wabah Covid-19. Salam sehat.

\section{Daftar Pustaka}

Ayuni, D., Marini, T., Fauziddin, M., \& Pahrul, Y. (2020). Kesiapan Guru Tk Menghadapi Pembelajaran Daring Masa Pandemi Covid-19. Jurnal Obsesi : Jurnal Pendidikan Anak Usia Dini, 5(1), 414. Https://Doi.Org/10.31004/Obsesi.V5i1.579 
Budiman, H. (2017). Peran Teknologi Informasi Dan Komunikasi Dalam Pendidikan. AlTadzkiyyah: Jurnal Pendidikan Islam, 8(1), 31. Https://Doi.Org/10.24042/Atjpi.V8i1.2095 Gusteti, M. U., Rahmalina, W., \& Desmariani, E. (2020). Pelatihan Membuat Video Pembelajaran Menarik Dengan Smartphone Pada Guru Adzkia 1). 4(1), 26-35.

Kurnia, R., \& Kurnia, R. (2020). Paud Lectura: Jurnal Pendidikan Anak Usia Dini, Vol 4, No 1, Oktober 2020. 4(1), 32-41. Https://Doi.Org/10.31849/Paud-Lectura.V

Mustakim. (2020). Efektivitas Pembelajaran Daring Menggunakan Media Online Selama Pandemi Covid-19 Pada Mata Pelajaran Matematika The Effectiveness Of E-Learning Using Online Media During The Covid-19 Pandemic In Mathematics. Al Asma: Journal Of Islamic Education, 2(1), 1-12.

Patandung, Y. (2017). Pengaruh Model Discovery Learning Terhadap Peningkatan Motivasi Belajar Ipa Siswa. Journal Of Educational Science And Technology (Est). Https://Doi.Org/10.26858/Est.V3i1.3508

Roki Hardianto, Fajrizal, Y. D. (2020). Pelatihan Menggunakan Sistem Informasi Geografis Lokasi Lembaga Swadaya Masyarakat Di Kesbangpol Pekanbaru. Jurnal Pengabdian Masyarakat Multidisiplin, 3(2), 78-85. Https://Doi.Org/10.36341/Jpm.V3i2.1006

Sadikin, A., \& Hamidah, A. (2020). Pembelajaran Daring Di Tengah Wabah Covid-19. Biodik, 6(2), 109-119. Https://Doi.Org/10.22437/Bio.V6i2.9759

Subekti, A. S., \& Kurniawati, L. A. (2020). Pelatihan Mendesain Pembelajaran Daring Menarik Selama Pandemi Covid-19 Dengan Teknologi Pembelajaran Sederhana. Dinamisia: Jurnal Pengabdian Kepada Masyarakat, 4(4), 588-595. Https://Doi.Org/10.31849/Dinamisia.V4i4.4679

Syarifudin, A. S. (2020). Impelementasi Pembelajaran Daring Untuk Meningkatkan Mutu Pendidikan Sebagai Dampak Diterapkannya Social Distancing. Jurnal Pendidikan Bahasa Dan Sastra Indonesia Metalingua, 5(1), 31-34. Https://Doi.Org/10.21107/Metalingua.V5i1.7072

Wulandari, M. (2016). Analisis Strategi Humas Untuk Meningkatkan Penerimaan Mahasiswa Prodi Pendidikan Administrasi Perkantoran Fakultas Ekonomi Unesa. Jurnal Administrasi Perkantoran (Jpap). 